Dr. sc. Hrvoje Kačer, redovni profesor u trajnom zvanju

Pravnog fakulteta Sveučilišta u Splitu

Dr. sc. Blanka Ivančić-Kačer, docentica

Pravnog fakulteta Sveučilišta u Splitu

\title{
O RJEŠAVANJU ANTINOMIJA I PRAVNIH PRAZNINA (POSEBNO) NA PRIMJERU ODNOSA ZAKONA O SPORTU1 I ZAKONA O OBVEZNIM ODNOSIMA²
}

\author{
UDK: 345 (497. 5) : 796/799 \\ Primljeno: 15. 10. 2016. \\ Pregledni rad
}

U ovom tekstu autori su pokušali pokazati i dokazati kako su antinomije i pravne praznine u pravu velika boljka, veliki i još uvijek neriješeni problem hrvatskog pozitivnog prava. Unatoč tome, ti problemi nikako se ne prepoznaju kao nekakav veliki problem, a o tome svjedoče i razmjerno rijetki stručni, a još više znanstveni tekstovi. Naravno, ni autori ne tvrde da su to najveći i/ili najakutniji hrvatski pravni problemi, ali po svemu zaslužuju da se netko njima započne sustavno baviti. Nakon izlaganja o načinu rješavanja antinomija i pravnih praznina uopće, autori su ponudili i dva konkretna primjera, smatrajući da njima dokazuju svoje teze. Oba primjera imaju veze sa sportskim pravom, jedan u poveznici sa Zakonom o vlasništvu, a drugi sa Zakonom o obveznim odnosima, kao s dva ključna zakona hrvatskog građanskog prava.

Ključne riječi: antinomije, pravne praznine, rješavanje, tumačenje, zakon

\section{UVOD}

Od svojih (pra)početaka, pravo je kao dio društvene stvarnosti i kao znanost učinilo ogroman napredak, ogromne promjene su se dogodile i gotovo da je moguće s punim pravom zaključiti kako nikada nitko u prošlosti ne bi mogao sa sigurnošću prognozirati ni smjer ni dosege dosadašnjeg procesa. Po naravi stvari, to na odgovarajući način vrijedi i pro futuro. Navedeno nema samo po sebi ili po naravi stvari nikakvu vrijednosnu kvalifikaciju, to nije samo po sebi ni dobro ni loše, još manje jako dobro ili jako loše, to samo znači priznanje jedne jako velike neizvjesnosti koja je objektivno determinirana mnogim čimbenicima, od neviđenog tehnološkog napretka (koji se ponekad u sportu samo prihvaća kao

Zakon o športu, NN 71/06., 150/08. (Uredba o dopuni Zakona o športu), 124/10., 124/11, 86/12 (čl. 1. st. 1. mijenja naziv zakona u Zakon o sportu), 94/13., 85/15., 19/16. (ispravak) - dalje: ZOS ili Zakon o sportu.

2 Zakon o obveznim odnosima, NN 35/05., 41/08., 125/11., 78/15. - dalje: ZOO ili Zakon o obveznim odnosima. 
takav, ${ }^{3}$ a ponekad se donose i zabrane uporabe nekih materijala radi očuvanja načela jednakosti ${ }^{4}$ ), preko stvarno nevjerojatnog napretka u metodama i vrstama treninga, pa sve do uporabe ili manipulacije (ovisno o tome tko ili s čijeg aspekta se nešto brani ili napada) svojstava zraka ili vode ili snijega ili leda (ovisno o kojem sportu se radi). U tom smislu, jedino je sigurno kako ništa nije sigurno, osim dosta velike nepripremljenosti tzv. općih odredbi kod donošenja kojih donositelj ili uopće nije imao u vidu primjenu na sport ili mu je to bilo potpuno sporedno.

Nekada davno, imali smo rimsko pravo i njegove zasade koje su apsolutno svi poštovali i od kojih je malo tko odstupao, neovisno o tome što je to bilo vrijeme robovlasništva. Došlo je i prošlo vrijeme feudalizma i podjela prava vlasništva po sadržaju, što danas izgleda kao gotovo nevjerojatna i nadasve neprihvatljiva konstrukcija. Prošlo je i vrijeme stvaranja gotovo svih današnjih država. Prošlo je i vrijeme svjetskih ratova, kao i tzv. hladnog rata (makar po nekima hladni rat traje i danas), ali je notorno da je taj rat (ako je i prestao) trajao barem do rušenja Berlinskog zida. Nakon tog rušenja, stvoren je velik broj novih država, gotovo sve uslijed raspada neprirodnih socijalističkih mastodonata koji su bili stvoreni uglavnom na sili, umjesto na prirodnoj koheziji (Savez Sovjetskih Socijalističkih Republika ili SSSR, Socijalistička Federativna Republika Jugoslavija ili SFRJ, Čehoslovačka ili ČSSR. Svaka nova država, već po naravi stvari, ima želju početi baš ab ovo ili barem gotovo ab ovo u smislu da ima što manju vezu sa svojom prethodnicom, drugim riječima, da se i na ovom planu pokaže i dokaže kao netko ili nešto (potpuno ili što potpunije) novo. Praktično postoje (samo) dvije krajnje opcije i ona treća kao njihova kombinacija, koja može biti manje ili više bliska jednoj od opcija. Prva opcija je tzv. clean start, što znači da više ne vrijedi ni jedna pravna norma bivše države, što je kao realno primijenjen model u povijesti apsolutno najrjeđa opcija. Druga opcija je da se iz prethodnog pravnog okvira preuzme (prenese) u prvom trenutku sve osim onih baš najneprihvatljivijih pravnih normi, ${ }^{5}$ a nakon toga se ,u hodu" radi na tome da se $u$ što kraćem roku ${ }^{6}$ ukupni pravni sustav dovede što prije u stanje u kojemu tih preuzetih pravnih normi ili neće biti ili će ih stvarno biti vrlo malo. Možemo iskreno nazvati srećom (makar bi bilo daleko bolje kada bismo mogli uporabiti pojam promišljenost umjesto sreće) to što su prigodom sučeljavanja s gotovo istom dvojbom i negdje 1945. god. ${ }^{7}$ i 1991. god. oni koji su bili u prigodi odlučivati, odlučili isto - preuzmimo ono što postoji, uz minimum nužnih pravnih sredstava.

Dugo je tako bilo na planu atletike u svezi s dopingom, odnosno s uporabom nedopuštenih

4 Takav je primjer zabrana posebnih materijala za kupaće kostime u plivanju. Međutim, sada, nakon nekoliko godina, već je oboreno dosta tih svjetskih rekorda postignutih u danas zabranjenim kostimima (podrazumijeva se da ti rekordi nisu dovođeni u pitanje jer su postignuti uporabom nečega što nije bilo zabranjeno u trenutku utrke koja je dovela do svjetskog rekorda).

5 U pravilu je kriterij politički određen.

6 U realnosti se ipak radi o roku koji se mjeri ne samo mjesecima, nego i godinama.

7 Nakon I. svjetskog rata, 01. XII. 1918. god. nastala je Kraljevina Srba, Hrvata i Slovenaca koja je trajala do prijelaznog razdoblja od 7. III. 1945. - 29. XI. 1945. u kojemu se radilo o Demokratskoj Federativnoj Jugoslaviji. Ustavotvorna skupština je 29. XI. 1945. ukinula monarhiju i tada je formirana nova država pod nazivom Federativna Narodna Republika Jugoslavija ili FNRJ. 
intervencija i nakon toga ,u hodu“ radimo na tome da se u što kraćem roku ukupni pravni sustav dovede što prije u stanje u kojemu tih preuzetih pravnih normi ili neće biti ili će ih stvarno biti jako malo! Iz današnje vremenske perspektive (a znamo da imamo gotovo nevjerojatnu produkciju propisa, ${ }^{8}$ da nismo ni približno zadovoljni kvalitetom donesenih propisa, ali i da u malo kojoj državi Ustavni sud ima toliko mnogo posla ${ }^{9}$ i toliki broj ukinutih zakona ili njihovih dijelova) samo zamislimo što bi bilo da se zakonodavac opteretio s neusporedivo više propisa nego što je stvarno učinio (a bilo bi ih neusporedivo više da nisu preuzeti propisi iz bivše države, sada kao akti nove države)! Ako je ovo što danas imamo nedovoljan pravni red, ${ }^{10}$ onda je potpuno sigurno da bismo, barem prema našem mišljenju, da se kojim slučajem drukčije odlučilo, danas imali pravi pravni nered. Naravno da pri tome postoje brojne olakotne okolnosti (npr. najjača i najobjektivnija je potreba prilagodbe hrvatskog pravnog sustava onome što se naziva europska pravna stečevina ili acquis communautaire), ${ }^{11}$ ali je vrlo loše to što praktično nema neke bitne razlike između različitih političkih opcija na vlasti. ${ }^{12}$ Tako npr. već i površna opcija pokazuje kako je sedmi saziv (a on uključuje vrijeme stjecanja punopravnog članstva u EU) donio neznatno više zakona od onog prethodnog ( 820 u odnosu na 814), ali je zato postotak zakona donesenih po hitnom postupku dramatično veći u šestom sazivu (86, $73 \%$ ) nego u sedmom (preko $80 \%$ zakona).

Neovisno o odabranoj opciji, svaki rad zakonodavca (posebno u novoj državi) znači vrlo težak, osjetljiv i mukotrpan posao na stvaranju pravnog sustava, na stvaranju pravnog okvira koji mora biti poticajan (a ne kočnica, kao što je to često slučaj) za ukupne društvene odnose i pri tome se boriti i izboriti za neprihvaćanje uobičajene floskule „pa što je problem staviti na papir tih par riječi“. Da je ta floskula kojom srećom (ili nesrećom) točna, ne bi postupak tumačenja u pravu bio tako značajan, ne bi postojao problem popunjavanja pravnih praznina, ne bi postojala ni potreba za pravnicima, jer bi posao pravnika mogao obaviti svatko. U konačnici, ne bi postojala ni općeprihvaćena pravna znanstvena disciplina nomotehnika.

\footnotetext{
8 Korisno je samo provjeriti web-stranicu Hrvatskog sabora (www.sabor.hr); ondje se nalaze stvarno nevjerojatni podaci. Tako je npr. u sedmom sazivu Hrvatskog sabora (2011. - 2015.) doneseno ukupno 820 zakona, od toga 658 po hitnom postupku, a 162 po redovnom postupku (to znači da je po hitnom postupku doneseno preko $80 \%$ zakona). U šestom sazivu (2008. - 2011.) doneseno je 814 zakona, od toga 706 po hitnom postupku, a 102 po redovnom postupku (to znači da je po hitnom postupku doneseno $86,73 \%$ zakona). U petom sazivu (2003. - 2007.) doneseno je 568 zakona, od toga 434 po hitnom postupku, a 131 po redovnom postupku (to znači da je po hitnom postupku doneseno $76,40 \%$ zakona). U četvrtom sazivu (2000. - 2003.) donesena su 622 zakona, od toga 417 po hitnom postupku, a 198 po redovnom postupku (to znači da je po hitnom postupku doneseno $67,04 \%$ zakona).

9 U konačnici to je izravan razlog nove nadležnosti Visokog upravnog suda Republike Hrvatske na planu apstraktne kontrole zakonitosti općih akata.

10 U usporedbi s onim što smo mogli imati, vjerujemo da je baš tako.

11 Uobičajena greška je smatranje da je taj dio zakonodavne aktivnosti započet 01. VII. 2013. kao danom stjecanja punopravnog članstva u EU za Republiku Hrvatsku. Stvarno, proces je počeo daleko prije, još od početka pregovora o pridruživanju.

12 Od naprijed navedenih, tzv. lijeva opcija bila je na vlasti od 2000. - 2003. i 2011. - 2015., a tzv. desna od 2002. -2011 .
} 
Stvarnost je upravo suprotna, formulacija svake pravne norme (pa i one najjednostavnije) ${ }^{13}$ izuzetno je zahtjevan intelektualni pothvat u kojemu pravna norma, kada se jednom donese i obznani, počinje svoj donekle samostalan život. Pri tome mislimo na to da volja donositelja (formirana u konkretnim društvenim okolnostima, vremenu i prostoru) ne predstavlja nešto što ograničava promjene u primjeni pravne norme, posebno nakon što je ciljno ili teleološko tumačenje ili interpretacija od statusa samo jedne od mnogih metoda tumačenja ili interpretacije došlo do apsolutno najvažnije, odlučujuće metode, metode koja dopušta čak i odstupanje od značenja što ga dopušta jezična metoda. ${ }^{14}$

Stvarnost je i to da smo već davno od one jednostavne i jedine podjele na javno i privatno pravo došli ne samo do stvaranja novih pravnih grana kao na tekućoj vrpci, nego i do pojave tzv. interdisciplina ili grana koje postupak tumačenja ili interpretacije još dodatno usložavaju. ${ }^{15}$ Jedna od tih novih pravnih grana jest sportsko pravo, sportsko pravo koje je stvarno prepuno svojih specifičnosti, ali i velikih različitosti u odnosu na npr. (opće) građansko pravo kao neku vrstu „majke“ privatnog prava, sportsko pravo koje je (primarna) tema ovog rada.

Baš sportsko pravo sa svim stvarno velikim bogatstvom svojega bića i gotovo strelovitog razvitka (što izaziva divljenje, gotovo strahopoštovanje) istodobno i gotovo zastrašuje u svezi s postupkom tumačenja ili interpretacije općenito, tim više ako se radi o odnosu sportskih pravnih normi prema onima općima (drugim riječima o primjeni načela rješavanja antinomija, a posebno lex specialis derogat legi generali na takve situacije, uključujući tu svakako i problem pravnih praznina). ${ }^{16}$ Stvarno je ključno pitanje gdje su limiti u postupku interpretacije ili tumačenja i jesu li (možda) na ovom tako specifičnom području drukčiji u odnosu na uobičajene. Vrlo jasno valja naglasiti problem popunjavanja pravnih praznina, radilo se tu o zakonskoj ili pravnoj analogiji, između kojih postoji velika razlika. Baš je to tema ovog teksta. Iako je u naslovu rada istaknut odnos Zakona o sportu prema Zakonu o obveznim odnosima, u samom radu se to širi i na (barem) dva druga slučaja, jedan iz područja

13 Vidjeti više o nomotehnici u: Ivo Borković, Nomotehnika, Pravni fakultet u Splitu, Split, 2000. god., Mihajlo Vuković - Đuro Vuković, Znanost o izradi pravnih propisa - nomotehnika, Informator, Zagreb, 1997. Vidjeti interesantan uradak s velikim brojem kvalitetnih primjera i objašnjenja u: Ivan Milotić, Domagoj Peranić, Nomotehnika - izrada općih akata s praktičnim primjerima, RRIF Plus, Zagreb, 2015. Slično i: Anamarija Livaja, Ivan Milotić, Komentar jedinstvenih nomotehničkih pravila, RRIF Plus, Zagreb, 2015.

14 Vidjeti više o tumačenju ili interpretaciji pravnih normi u: Berislav Perić, Država i pravni sustav, III. izdanje, Narodne novine, Zagreb, 1988., str. 241-295, Nikola Visković, Pojam prava, drugo dopunjeno izdanje, Logos, Split, 1981., str. 287-304, Oleg Mandić, Sistem i interpretacija prava, Narodne novine, Zagreb, 1971., str. 177-210, Radomir D. Lukić, Uvod u pravo, SUPJ, Beograd, 1961., str. 285-357.

15 Minimum usložavanja jest prethodno utvrđivanje koja od sastavnica ima prevagu i koliko međusobne eventualne suprotnosti eventualno onemogućavaju neki od mogućih zaključaka.

16 Pravna praznina predstavlja poseban oblik konkretnog slučaja koji treba interpretirati i to takav za koji zakonodavac nije predvidio pravnu normu koja bi regulirala takve slučajeve. - Vidjeti tako u: Oleg Mandić, op. cit., str. 142. 
građanskog procesnog prava i drugi iz područja vlasničkog prava, a na odgovarajući je način moguća primjena izvedenih zaključaka i na bilo koji drugi zakon. ${ }^{17}$

Sam rad je koncipiran tako da nakon ovog uvodnog dijela slijede posebni dijelovi o pravnim vrelima, zatim o tumačenju ili interpretaciji pravnih normi, uključujući rješavanje antinomija i pravnih praznina, postavljanje i analiza problema, te na kraju zaključak.

\section{PRAVNA VRELA}

Uobičajeno je u dijelu znanstvenog rada s ovim ili sličnim naslovom krenuti s ustavom kao najvišim pravnim aktom u svakoj uređenoj državi. ${ }^{18}$ Po uobičajenom obrascu, slijedili bi zakoni, podzakonski akti, pravni običaji, pravna znanost i sudska praksa. U ovom konkretnom slučaju narav stvari, ali i inertnost zakonodavca, diktiraju donekle drukčiji pristup. Dakle, na prvo mjesto ćemo svakako i ovaj put staviti Ustav Republike Hrvatske ${ }^{19}$ kao najviši pravni akt, ali ćemo odmah do Ustava staviti i Zakon o potvrđivanju sporazuma o stabilizaciji i pridruživanju između Republike Hrvatske i europskih zajednica i njihovih država članica ${ }^{20}$ kao međunarodni ugovor (koji je, naravno, ratificiran i proglašen sukladno Ustavu) temeljem kojega smo u konačnici 01. VII. 2013. god. postali punopravna članica Europske unije (EU), od kada nema više klasične podjele na hrvatsko i europsko pravo, jer je svaka hrvatska pravna norma istodobno i europska pravna norma, a svaka europska pravna norma je istodobno i hrvatska pravna norma. ${ }^{21} \mathrm{U}$ formalnom određivanju hijerarhije Ustav je svakako najviši akt, ali u praksi, barem dok smo u statusu članice EU i drugih snažnih međunarodnih asocijacija, ${ }^{22}$ moramo priznati da to baš i nije tako, a nešto slično proizlazi i iz dugogodišnjeg jasnog ${ }^{23}$ stava Ustavnog suda prema kojemu odbija postupati na planu utvrđivanja je li neka norma međunarodnog ugovora $\mathrm{u}$ skladu s Ustavom ili (eventualno) nije. Zbog toga što se radi o zakonima čiji odnos

17 Istina, jednako tako bi bilo moguće i posebne tekstove, čak i šire i/ili drukčije od ovoga, posvetiti svakome od tih posebnih pitanja.

18 Čudnu iznimku u tom smislu predstavlja Velika Britanija kao država koja nema ustav u klasičnom smislu te riječi.

19 Ustav Republike Hrvatske, NN 56/90., 135/97., 8/98. - pročišćeni tekst, 113/00., 124/00. pročišćeni tekst, 28/01., 41/01. - pročišćeni tekst, 55/01. 76/10 - Promjena Ustava, 85/10. - pročišćeni tekst - dalje: Ustav.

20 Zakon o potvrđivanju sporazuma o stabilizaciji i pridruživanju između Republike Hrvatske i europskih zajednica i njihovih država članica, NN MU 14/2001 od 27. XII. 2001. - dalje: Sporazum.

21 Nešto slično se, ali daleko ranije, dogodilo s jednim važnim međunarodnim ugovorom čiji potpisnici nisu nužno članice EU. Radi se o Konvenciji za zaštitu ljudskih prava i temeljnih sloboda NN - Međunarodni ugovori broj 18/97., 6/99. - pročišćeni tekst, 8/99. - ispravak, 14/02. i 1/06. nastavno: Konvencija ili Konvencija za zaštitu ljudskih prava i temeljnih sloboda. Vidjeti više o tom važnom aktu, uključujući i praksu Ustavnog suda u: Jasna Omejec, Konvencija za zaštitu ljudskih prava i temeljnih sloboda u praksi Europskog suda za ljudska prava - STRASBOURŚKI ACQUIS, drugo i dopunjeno izdanje, Novi informator, Zagreb, 2014. (1552 stranice).

22 U prvom redu mislimo na Sjevernoamerički atlantski savez ili NATO.

${ }^{23}$ Svatko realističan dodat će: i lako razumljivog. 
Dr. sc. Hrvoje Kačer i dr. sc. Blanka Ivančić-Kačer: O rješavanju antinomija i pravnih praznina ... Zbornik radova Pravnog fakulteta u Splitu, god. 54, 2/2017., str. 397.- 414.

prema Zakonu o sportu proučavamo, pravna su vrela, pored toga zakona, i Zakon o obveznim odnosima, Zakon o vlasništvu i drugim stvarnim pravima ${ }^{24}$ i Zakon o parničnom postupku. ${ }^{25}$

Činjenica je da naš zakonodavac izbjegava unijeti u zakonski tekst pravila o rješavanju antinomija. O tome modusu operandi zakonodavca moglo bi se raspravljati, ali je potpuno notorno da je baš takav i, kada je već tako, onda se u tom kontekstu mora istražiti i utvrditi (znanstvena jer zakonskih i nema) pravila o antinomijama, što u ovom tekstu i radimo. Budući da zakoni ne sadrže navedena pravila, to na neki način silom prilika ili po naravi stvari u prvi plan naglo i snažno ulaze i sudska praksa ${ }^{26}$ (što i nije neuobičajeno iako nismo dio anglosaksonskog precedentnog prava, nego kontinentalnoeuropskog pravnog kruga) i pravna znanost.

Što se tiče sudske prakse, ona je s jedne strane vrlo ustaljena u nedovođenju osnovnih postulata za rješavanje antinomija uopće u pitanje, ali s druge strane

24 Zakon o vlasništvu i drugim stvarnim pravima; pročišćeni tekst objavljen je u NN 81/15, a taj tekst sadržava: Zakon o vlasništvu i drugim stvarnim pravima (Narodne novine, br. 91/96), Zakon o izmjenama i dopunama Zakona o prodaji stanova na kojima postoji stanarsko pravo (Narodne novine, br. 68/98), Odluku Ustavnog suda Republike Hrvatske br. U-I-58/97, U-I-235/97,U-I-237/97, U-I-1053/97 i U-I1054/97 od 17. studenoga 1999. (Narodne novine, br. 137/99), Odluku Ustavnog suda Republike Hrvatske br. U-I-1094/99 od 9. veljače 2000. (Narodne novine, br. 22/00), Zakon o dopuni Zakona o vlasništvu i drugim stvarnim pravima (Narodne novine br. 37/00), Zakon o izmjeni i dopuni Zakona o vlasništvu i drugim stvarnim pravima (Narodne novine, br. 114/01), Zakon o izmjenama i dopunama Zakona o vlasništvu i drugim stvarnim pravima (Narodne novine, br. 141/06), Zakon o izmjenama i dopunama Zakona o vlasništvu i drugim stvarnim pravima (Narodne novine, br. 146/08), Zakon o izmjenama Zakona o vlasništvu i drugim stvarnim pravima (Narodne novine, br. 38/09), Zakon o izmjeni i dopuni Zakona o vlasništvu i drugim stvarnim pravima (Narodne novine, br. 153/09), Zakon o izmjeni Zakona o vlasništvu i drugim stvarnim pravima (Narodne novine, br. 143/12) i Zakon o izmjeni Zakona o vlasništvu i drugim stvarnim pravima (Narodne novine, br. 152/14), u kojima je utvrđeno vrijeme njihova stupanja na snagu. - dalje: ZV ili Zakon o vlasništvu. Po nekima će izgledati pretjerano, ali mi smatramo pravom pravnom katastrofom što prije 01. I. 2017. god. nije produžena odgoda primjene načela povjerenja u zemljišnu knjigu. Može se kasnije pravdati da je to učinjeno namjerno, mi smo uvjereni da je to propust, a ako je bila namjera, onda je na pogrešnom temelju jer ništa se bitno nije promijenilo u prethodnom razdoblju odgode pa da ona više ne bi bila potrebna.

25 Zakon o parničnom postupku, NN 148/11. - pročišćeni tekst, a taj tekst sadržava: Zakon o parničnom postupku, objavljen u SL SFRJ, br. 4/77. i 36/77. (ispr.) te njegove izmjene i dopune objavljene u SL SFRJ, br. 6/80., 36/80., 43/82., 69/82., 58/84., 74/87., 57/89., 20/90., 27/90. i 35/91., Zakon o preuzimanju Zakona o parničnom postupku, objavljen u NN, br. 53/91. (stupio na snagu 8. listopada 1991.), Zakon o izmjenama Zakona o parničnom postupku, objavljen u NN, br. 91/92. (stupio na snagu 8. siječnja 1993.), Zakon o izmjenama i dopunama Zakona o parničnom postupku, objavljen u NN, br. 112/99. (stupio na snagu 6. studenoga 1999.), članak 50. Zakona o arbitraži, objavljen u NN, br. 88/01. (stupio na snagu 19. listopada 2001.), Zakon o izmjenama i dopunama Zakona o parničnom postupku, objavljen NN, br. 117/03. (stupio na snagu 1. prosinca 2003.), članak 129. Zakona o izmjenama i dopunama Ovršnog zakona, objavljen u NN, br. 88/05. (stupio na snagu 28. srpnja 2005.), Odluku USRH, br. U-I-1569/04. i dr., objavljena u NN, br. 2/07. i 96/08., Zakon o izmjenama i dopunama Zakona o parničnom postupku, objavljen u NN, br. 84/08. (stupio na snagu 1. listopada 2008., osim odredbe čl. 49. koja stupa na snagu na dan prijama Republike Hrvatske u Europsku uniju), ispravak Zakona o izmjenama i dopunama Zakona o parničnom postupku, objavljen u NN, br. 123/08.) te Zakon o izmjenama i dopunama Zakona o parničnom postupku, objavljen u NN, br. 57/11. (stupio na snagu 2. lipnja 2011., osim odredbi čl. 14., čl. 29. u dijelu koji se odnosi na Europski sud i čl. 49. koje stupaju na snagu na dan prijama Republike Hrvatske u Europsku uniju, 25/13. - dalje: ZPP ili Zakon o parničnom postupku.

26 Vidjeti vrlo dobru doktorsku disertaciju pod naslovom Sudska presuda kao izvor prava - Budimir Košutić, Univerzitet u Beogradu, 1973. god. (171 stranica). Vidjeti i drugu, bitno noviju, pod naslovom Argumentacija u odlukama hrvatskih sudova, Pravni fakultet Sveučilišta u Splitu, Split, svibanj 2003. (223 stranice). 
istodobno i vrlo siromašna u stvaranju novih pravila kao iznimaka koje dopuštaju odstupanje od osnovnog pravila. U stranoj usporedivoj praksi tako postoje (ne nužno brojni) slučajevi u kojima se zanemaruje princip hijerarhije (kao inače najmanje osporavan, kao onaj za koji mnogi smatraju kako i ne trpi iznimke) u korist nekog drugog, pa i tako da se zakonom dovede u pitanje (promijeni) i odredba iz Ustava (to znači da je kriterij hijerarhije ostao bez prednosti pred kriterijem specijalnosti i/ ili vremena). ${ }^{27}$ Iako nema formalne izravne zabrane da tako nešto napravi od strane bilo kojeg suda, ipak bi po naravi stvari to trebalo biti u prvom redu privilegij (ali i obveza, to je vrlo značajno da bi bilo ne samo učinkovito, nego i neprikladno za ignoriranje šutnjom ili pasivnošću) Vrhovnog suda Republike Hrvatske (koji je po Ustavu najviši sud u Republici Hrvatskoj) i Ustavnog suda Republike Hrvatske kao suda sui generis. Praktično je svejedno bi li se radilo o opciji u kojoj se unutar jednog konkretnog predmeta zapravo donese cijelo jedno malo istraživanje (pri čemu iza zaključaka stoji autoritet donositelja) ili bi se to dogodilo izvan konteksta konkretnog predmeta, npr. stavovi opće sjednice Vrhovnog suda RH i slično. Izgleda nam kako bi najdragocjeniji doprinos bio onaj na području primjene načela analogije, posebno u svezi s popunjavanjem pravnih praznina (kada se tu prazninu popuni, onda imamo jednu potpuno novu situaciju jer pravne praznine, barem one i onakve kakva je do tada postojala, više nema). Bitno je pri tome naglasiti kako sudska praksa djeluje ne samo snagom argumenta, nego i argumentom snage, a pod određenim uvjetima ima (odnosno može imati) i povratan učinak. ${ }^{28}$

Što se tiče pravne znanosti, poznato je da ona djeluje (samo) snagom argumenta, osim u izdvojenim slučajevima u kojima je znanstvenik na neki način homo duplex jer obnaša neku važnu ulogu u nekoj od tri grane vlasti, pa tako ima prigodu snazi argumenta dodati i argument snage. U našoj ne tako davnoj praksi nemali je broj takvih slučajeva u svim granama vlasti, ali ipak najviše u onoj sudbenoj, uključujući tu i Ustavni sud kao sud sui generis. ${ }^{29}$ Interesantno je kao ideju (makar ne baš novu i sigurno ne kao prihvaćenu) spomenuti njemačkog pravnog autora Theodora Sternberga koji je u svojoj poznatoj knjizi Uvod u pravnu znanost elaborirao ideju prema kojoj bi pravnoj znanosti trebalo priznati status glavnog izvora prava. Prema njegovu mišljenju, društveni odnosi su sve složeniji (to se kao trend nastavilo do danas, a očito će tako biti i pro futuro) i država neće moći svojim aktima zahvatiti svu tu složenost, diferenciranost i začuđujuću kvantitetu društvenih odnosa. Zbog toga je potreban novi čimbenik, a po svojoj kvaliteti najpogodnija za to jest pravna

27 Norberto Bobbio, Eseji iz teorije prava, Logos, Split, 1988., str. 134.

28 To se, istina, ne odnosi na slučajeve koji su pravomoćno presuđeni, ali se zato odnosi na sve druge.

29 Ograničavajući se samo na vrijeme od osamostaljenja Republike Hrvatske, svi predsjednici Ustavnog suda RH bili su i istaknuti znanstvenici s titulom doktora pravnih znanosti (Jadranko Crnić, Smiljko Sokol, Petar Klarić, Željko Potočnjak, Jasna Omejec, Miroslav Šeparović), a velik je i broj sudaca toga suda s notornim znanstvenim renomeom (Aldo Radolović. Snježana Bagić...). S Vrhovnog suda RH tako možemo navesti Ivicu Crnića, Ivu Grbina, Antu Perkušića, Andriju Erakovića, Jadranka Juga. Iz izvršne vlasti možda su najistaknutiji predsjednik Svjetskog žrtvoslovnog društva Zvonimir Šeparović i akademik Davorin Rudolf, a iz redova zastupnika u Hrvatskom saboru svakako je najpoznatiji Ivo Josipović koji je u jednom mandatu bio i Predsjednik Republike. 
znanost, odnosno njezini stručnjaci. ${ }^{30}$ Nekome tko je znanstvenik, ovo kao ideja može biti (čak i jako) simpatično, tim prije kada se uzme u obzir kako Švicarski građanski zakonik sadrži čl. 1. st. 3. u kojemu preporučuje sucima neka se u suđenjima nadahnjuju stavovima koji su uvriježeni u pravnoj doktrini. ${ }^{31}$ Ipak, već i malim odmakom od mogućeg zanosa ovom idejom treba se vratiti u stvarnost i biti svjestan ne samo načela trodiobe vlasti u kojoj nema mjesta znanosti kao zakonodavnoj vlasti (pa ni sui generis), nego i činjenice da su pravna znanost i pravni znanstvenici jako širok pojam koji obuhvaća mnoge, pored ostaloga i one loše znanstvenike. Dodatan problem jest i to što među onima koju jesu dobri ima ne baš beznačajan broj onih koji su jako daleko od bilo kakve prakse. ${ }^{32}$ Ako bismo se ograničili samo na one najbolje, samo na vrhunske pravne znanstvenike, postavlja se pitanje kriterija po kojemu će se ti razlikovati od ostalih. Nadalje, iako nas praksa u formalnom smislu demantira (od hrvatske $\mathrm{u}$ kojoj se $\mathrm{u}$ znanstvena i znanstveno-nastavna zvanja provode izbori u polje prava, bez preciziranja grane, preko strane i posebno njemačke u kojoj jedan „stručnjak“ figurira kao autor knjiga iz potpuno udaljenih pravnih tema, a prava istina je da on samo objedinjuje kao stariji i ugledniji autor niz onih manje afirmiranih), ipak je notorno da je ne samo potreba nego i nužnost specijalizacije otišla toliko daleko da je broj znanstvenika kojima je forte baš konkretno, dosta usko područje, jako malen. Primjenjujući to in concreto dogodilo bi se da u nekoj supspecijalnoj temi ulogu zakonodavca zamijeni jedan znanstvenik, a to je ipak bliže noćnoj mori nego idealnoj situaciji. Prema našem mišljenju, daleko je bolje ostaviti znanstvenicima ono što imaju i sada - neka služe kao mogući korektiv svim granama vlasti na način utjecanja snagom argumenta, a ako rezultat ipak bude protiv onoga što misle, neka pišu i znanstveno se obračunavaju s bilo kojom granom vlasti, što im sveučilišna autonomija ne samo omogućava, nego ih na to na neki način i obvezuje. Pri tome apsolutno ne smatramo prihvatljivim često ponavljani argument prema kojemu je nedostatak znanstvene interpretacije u tome što pravna znanost, kada interpretira, nema ispred sebe konkretan slučaj nego tumačenje daje apstraktno i uopćeno. ${ }^{33}$ Naime, točno je da je moguce interpretaciju davati uopćeno, ali to je samo jedna od mogućnosti. Druga je svakako dati interpretaciju ili tumačenje na konkretnom slučaju. Dodatno bi svakako kao cilj trebalo postaviti da znanost općenito, pa tako ni pravna znanost, ne smije imati samu sebe za svrhu nego svrha treba biti postizanje praktičnih poboljšica na određenom području života. ${ }^{34}$

30 Prema: Berislav Perić, op. cit., str. 185 i dalje.

31 Nešto slično postoji u medicinskom pravu kao obveza liječnika primjenjivati poznate i priznate metode i sredstva liječenja. Međutim, činjenica je da to vrlo negativno djeluje na bilo kakva istraživanja i smatra se glavnim uzrokom prevladavanja tzv. defanzivne medicine. Primijenjeno na znanstvenike kao glavni izvor prava u opisanoj ideji trebalo bi voditi računa i o ovom aspektu.

32 To je samo donekle razumljivo ako se ne radi o pozitivnim znanostima, ali kao činjenica postoji i kod njih i tako dodatno smanjuje broj onih koji spadaju u dobre ili jako dobre znanstvenike.

33 Vidjeti tako npr. u: Radomir D. Lukić, op. cit., str. 298.

34 Umjesto toga, danas je dosta česta pojava prilično podrugljivo komentiranje pisanja autora koji su pravni znanstvenici u svim medijima osim u onim klasičnim znanstvenim, što je svakako odlazak u jednu (lošu) krajnost. 
Prema nekim autorima postoji podjela pravnih vrela na ona vrela koja su pravna ili juridička i ona koja su izvanpravna ili metajuridička. Među ovima drugima, posebno se ističe narav stvari ili rerum natura..$^{35}$ Potpuno je sigurno kako je ovo pravno vrelo ili pravno vrelo sui generis prilično nepravedno zanemareno, a upravo nam ono može biti od velike pomoći u postupku tumačenja u pravu, posebno kod popunjavanja pravnih praznina. Inače se priroda ili narav stvari u pravilu povezuje s prirodnim pravom, ali treba priznati da je uspijevala (po nama i uspijevat ce i pro futuro) opstati i onda kada to nije bio slučaj s ukupnom školom ili idejom prirodnog prava. ${ }^{36}$

\section{TUMAČENJE ILI INTERPRETACIJA PRAVNIH NORMI, UKLJUČUJUĆI RJEŠAVANJE ANTINOMIJA I PRAVNIH PRAZNINA}

\section{III.1. TUMAČENJE ILI INTERPRETACIJA PRAVNIH NORMI}

Već na prvoj godini studija, studenti pravnih fakulteta širom svijeta započinju svoj velik, težak i neizvjestan put od budućeg pravnika početnika ${ }^{37}$ prema vrhunskom pravniku, s temeljnom motivacijskom porukom prema kojoj su, unatoč tome što je mjesta na vrhu struke vrlo malo, ipak načelno svima dostižna i o svakome od nas koji počinjemo tu životnu utrku i o našoj volji i predanosti i mukotrpnom radu ovisi do koje ćemo točke u poznatoj izreci PER ASPERA AD ASTRA konačno stići. Na navedenom je putu jedna od najvažnijih postaja baš ona o tumačenju ili interpretaciji u pravu, jer onaj pravnik koji taj dio zanemari jednostavno ne može biti dobar (a još manje vrhunski) pravnik.

Tumačenje ili interpretacija su (kao sinonimi) pojmovi koji nisu ograničeni samo na pravo, nego postoje i općenito. Po naravi stvari, pojmom tumačenja se, sukladno navedenom, bave razne znanosti, a samo jedna od njih je i ona pravna i ona u svojem fokusu ima tumačenje ili interpretaciju u pravu. Tumačenje se definira kao djelatnost kojom se utvrđuje značenje ili smisao neke materijalne pojave koja je i upotrijebljena da bi se dotično značenje priopćilo, a materijalna pojava koja je nositelj značenja

35 Ivo Krbek, Prilog teoriji o pojmu prava, Zagreb, 1952., str. 74, prema: Berislav Perić, Struktura prava, I. dio, treće izdanje, Narodne novine, Zagreb, 1972., str. 189.

36 Koliko je ideja prirodnog prava snažna i na neki način bezvremenska, pokazuje na određeni način $\mathrm{i}$ činjenica da potpuno sigurno najveće (po kriteriju broja sudionika i broja država iz kojih isti dolaze) $\mathrm{i}$ najznačajnije (po mnogim kriterijima, od rasta po mnogim pokazateljima do značenja i trajnosti i samog savjetovanja koje datira od 1987. i pokrovitelja - UNESCO te višednevnosti koja jamči ozbiljnost i temeljitost) pravničko znanstveno i stručno savjetovanje koje se jednom godišnje (13.-17. prosinca) održava na Kopaoniku pod nazivom Kopaonička škola prirodnog prava, u organizaciji Univerzitas iuris naturalis Copaonici.

37 Što je bitno niža kategorija od kategorije pravnika početnika koji jest početnik, ali ipak ima diplomu pravnog fakulteta. 
naziva se znak. ${ }^{38}$ Interpretacija ili tumačenje u pravu je, pojednostavljeno, postupak utvrđivanja pravog značenja neke pravne norme. To može samo na prvi pogled ili prima facie izgledati jednostavan zadatak, a svaka detaljnija analiza pokazat ce upravo suprotno - to je vrlo zahtjevan, visokostručan ili sofisticiran zadatak koji uspješno mogu obaviti samo stvarno dobri pravnici, uz pažljivu i stručnu primjenu metoda tumačenja ili interpretacije. Iako postoji mnogo metoda u ovom trenutku (a vjerujemo i daleko dalje), apsolutni prioritet ima ona ciljna ili teleološka, tako da ćemo se u prvom redu njoj posvetiti, a neke druge spomenuti vrlo kratko i samo osnovne informacije radi.

Svaka pravna norma (ne samo zakon, ne samo podzakonski akti, nego i uopće svaki pravni dokument) predstavlja skup riječi koje imaju određeno značenje ili određena značenja koja treba utvrditi. Uslijed čitavog niza uzroka (pri čemu bogatstvo nekog jezika, kao i gramatika imaju značajnu ulogu) tom sklopu riječi (znakova) često je dosta složeno dati pravo značenje i baš na tom zadatku jako se lako i dobro vidi vrsnoća onoga tko primjenjuje (tumači) pravnu normu. Postoje općeprihvaćena pravila tumačenja, u dosta velikoj mjeri je prihvaćen i njihov međusobni odnos, ali ipak u praksi (pre)često dolazi do problema. To je svojstvo koje nije posebnost samo kontinentalnoeuropskog prava (kojem i pripada hrvatski pravni sustav) nego vrijedi i kao svojstvo precedentnog prava, što problem svakako čini još značajnijim i (još) općenitijim.

Ciljno ili teleološko tumačenje jest tumačenje koje ima apsolutnu prednost u acquis communautaire i zato je (ne samo radi znanosti, nego i prakse) značajno ukazati na barem ono osnovno i najvažnije (uz podatke gdje se i kako može produbiti znanje) o tom tumačenju. Ova metoda tumačenja jest metoda kojom se ispituje uloga pravne norme u društvu i zaključuje da je njezino pravo značenje u određenom pravnom odnosu ono značenje koje najbolje izražava vladajuće društvene ciljeve. Upravo se ciljna metoda smatra odlučujućom u svim onim slučajevima postojanja više mogućih (vjerojatnih) pravih značenja, pa njezina uporaba mora otkriti ono (jedino) pravo značenje te pravne norme. Zbog toga je ciljno tumačenje najvažnije, odlučno i završno u postupku tumačenja (razumijevanja) pravnih normi, a sva druga pravila tumačenja njemu su podređena i njemu služe.$^{39}$ Inače, razlikuju se subjektivno ciljno (smatra se i statičkim) i objektivno ciljno tumačenje (smatra se i dinamičkim). Iako je svoju pravu potvrdu ciljno tumačenje dobilo nekako u novije vrijeme, treba spomenuti da je jedna od najznačajnijih ${ }^{40}$ svjetskih kodifikacija prava. Austrijski BGB ili Opći građanski zakonik ili OGZ iz 1811. god. u \& 6. propisao je obvezu ustanovljavanja - utvrđivanja ,jasne nakane zakonodavca“. Drugim riječima, to je i tada bilo i (do) danas ostalo utvrđenje što je ratio legis (ne ulazeći u posebnosti).

38 Radomir D. Lukić, op. cit., str. 285.

39 Vidjeti tako u: Nikola Visković, Teorija države i prava, Birotehnika, Zagreb, 2001., str. 250., više o tome i u: Oleg Mandić, Sistem i interpretacija prava, Narodne novine, Zagreb, 1971. god., str. 201. i dalje.

40 A za hrvatsku pravnu povijest apsolutno najznačajnija, neusporedivo s bilo kojom drugom. 
Ono što stvarno treba naglasiti (i nikada ne zanemariti) jest vječna dvojba smije li se ciljnom metodom ići izvan onoga što dopušta jezično tumačenje. Jedni smatraju da ciljna metoda služi baš zato kako bi ispravila nejasnoće jezične metode (u prvom redu, ali ne samo te, nego i drugih), pa to nema prave svrhe ako joj se postave takva ograničenja. Drugi pak smatraju da normotvorac uvijek može normu promijeniti ako njome nije zadovoljan (pa čak is povratnim učinkom) ${ }^{41}$ pa nema ni potrebe ni opravdanja tako teško povrijediti pravnu sigurnost kao što je slučaj ako se ciljnom metodom utvrđuje značenje koje nije jedno od onih što ih daje jezična metoda. Čak i ako se dopusti ovakvo postupanje kao iznimka (što je barem dvojbeno), opće pravilo moralo bi biti da se ciljna (ali i svaka druga) metoda moraju kretati u okvirima koje određuje jezična metoda, a iznimka bi samo jako iznimno smjela doći u obzir.

Jezična metoda tumačenja obično predstavlja početak postupka tumačenja. Ona pokazuje značenje pojedinih riječi od kojih se sastoji pravna norma. Analizirajući značenje riječi, njihov raspored, gramatičku povezanost i interpunkcije, to tumačenje (interpretacija) prikazuje smisao što ga izražavaju pojedine riječi ${ }^{42}$ pri čemu treba respektirati činjenicu da je hrvatski jezik izuzetno složen, što tumačenje u pravilu može samo otežati, nikako ne olakšati. Njezinom se uporabom nastoji utvrditi smisao koji proizlazi iz uporabljenih riječi, bez ikakva obzira (u toj fazi) na ratio legis, ili na konkretan slučaj koji se rješava. Jezičnoj je metodi svrha istražiti značenje pravnog propisa, uzetog za sebe kao skup riječi koje u svojoj međusobnoj povezanosti imaju određeni smisao. Ovim tumačenjem se dobiva jedno (rjeđe) ili više (češće) mogućih značenja pojedinih riječi i cjeline pravne norme. Pri tome je, naravno, važan svaki detalj koji može (ali i ne mora) biti odlučan. Npr. može biti bitno i koje je glagolsko vrijeme upotrijebljeno (npr. ako je u nekoj normi propisano da "... ce se..." određeno pitanje “... urediti posebnim propisom.", tada je jasno da se misli na propis koji u to vrijeme još nije donesen, jer se uporabilo buduće vrijeme), iako postignuti rezultat mora biti provjeren i uporabom drugih metoda, a posebno teleološkom metodom tumačenja. U pravilu je jezična metoda tek priprema i pretpostavka za uporabu drugih metoda uz pomoć kojih se konačno otkriva pravo značenje iz kruga mogućih značenja. Što znače pojedini izrazi iz normativnih odredaba, spoznaje se tek primjenom drugih pravila tumačenja, te na kraju ciljnim tumačenjem kao odlučujućim. ${ }^{43}$

Nakon jezične metode (a prije ciljne ili teleološke), u pravilu se rabi logičko tumačenje, posebno uporaba brojnih argumenata formuliranih u nizu logičkih pravila, pri čemu postoje principi opće logike i posebni principi ili načela pravne logike, koji sadrže i specifičnosti kao posljedicu predmeta na koji se odnose. Kao

41 Osim ako se radi o kaznenom i prekršajnom pravu gdje to po međunarodnim standardima ne dolazi u obzir.

${ }^{42}$,To se radi tako da se na pravne odredbe koje su nejasne ili višeznačne primjenjuju pravila leksikologije, sintakse i gramatike što vrijede u društvu subjekta-tumača." - Nikola Visković, op. cit., str. 248. Treba naglasiti da je navedena tvrdnja samo dijelom ili samo uvjetno točna, jer se baš i stanje, odnosno hipoteza da je nešto nejasno ili višeznačno ili pak nije, provjerava i utvrđuje primjenom navedenih pravila, što znači da ista treba primijeniti na svaku pravnu normu, a ne samo na nejasne i višeznačne.

43 Vidjeti tako u: Nikola Visković, op. cit., str. 249. Ova i ranije postojeća tvrdnja su sada, kad smo dio EU, još daleko više dobile na značenju. 
primjere načela pravne logike moguće je tako navesti argumentum a simili ad simile (argument sličnosti), argumentum a contrario (argument suprotnosti), argumentum a fortiori koji uključuje argumentum a minori ad maius (argument zaključivanja od manjeg na veće) i argumentum a maiori ad minus (argument zaključivanja od većeg na manje), argumentum per analogiam (argument zaključivanja po sličnosti), pri čemu se razlikuju zakonska analogija (analogia legis) i pravna analogija (analogia iuris), argument naravi stvari (argumentum rerum natura), argument autoriteta (argumentum ab exemplo), argumentum a completudine (prema kojemu je pravni sustav potpun), ${ }^{44}$ ali i argumentum a cohaerentia (prema kojemu je pravni sustav usklađena cjelina i zato u njemu ne bi smjelo biti antinomija, ali i spoznaji da pravni sustav nije usklađena cjelina). ${ }^{45}$

\section{III.2. RJEŠAVANJE ANTINOMIJA I PRAVNIH PRAZNINA}

\section{III.2.1. O ANTINOMIJAMA}

Rješavanje antinomija i pravnih praznina jest condicio sine qua non bez kojega veći dio tumačenja ili interpretacije ne bi uopće bio moguć. Bolji argument in favorem velikog značenja ove tematike očito nije ni potreban.

Antinomija (latinski antinomia, engleski antimony, njemački Antinomie) ${ }^{46}$ proturječnost je unutar zakona ili pravnog sustava koja zahtijeva najprije utvrđivanje postojanja antinomija i potom iznalaženje kriterija za rješavanje te ili tih antinomija. Radi se o dva različita problema, pri čemu se možemo složiti da je ipak lakše i jednostavnije utvrditi postojanje dvije antinomične norme, a teže i složenije utvrditi prava kako tu antinomičnost riješiti najprije načelno i nakon toga in concreto. Jedna od najpoznatijih i najprihvaćenijih definicija definira antinomiju kao proturječje između dviju ili više pravnih normi ili načela, koje se naročito izražava u povodu praktične primjene tih normi ili načela na jedna konkretan slučaj ili na jednu kategoriju pojedinih slučajeva. ${ }^{47}$

Dok bi čovjek s ulice, na pitanje kojoj od dviju inkompatibilnih normi treba dati prednost, vjerojatno odgovorio „onoj pravednijoj“, pravo redovito daje drukčiji odgovor, opskrbljujući tumača s nekoliko kriterija na izbor, koji imaju evidentan cilj da spriječe djelovanje osobnih preferencija. Kao što znamo, najčešće se usvajaju kriteriji kronologije, hijerarhije i specijalnosti. ${ }^{48} \mathrm{Ni}$ kriterij kronologije ni kriterij dalje.

44 Vidjeti tako u: Marijan Pavčnik, Teorija prava, Cankarjeva založba, Ljubljana, 2001., str. 391. i

45 Žaklina Harašić, Argumentacija u odlukama hrvatskih sudova, Pravni fakultet Sveučilišta u Splitu, Split, svibanj 2003., str. 56.

46 Pravni leksikon, Leksikografski zavod Miroslav Krleža, Zagreb, 2007., str. 37.

47 Berislav Perić, Država i pravni sustav, III. Izdanje, Narodne novine, Zagreb, 1988., str. 249.

48 Norberto Bobbio, op. cit., str. 125. 
Dr. sc. Hrvoje Kačer i dr. sc. Blanka Ivančić-Kačer: O rješavanju antinomija i pravnih praznina ... Zbornik radova Pravnog fakulteta u Splitu, god. 54, 2/2017., str. 397.- 414.

hijerarhije se (za razliku od kriterija specijalnosti) uopće ne obaziru na predmet regulative, odnosno na predmet pravne norme.

Kriterij kronologije temelji se na vremenu početka postojanja neke pravne norme, točnije kriterij je vrijeme od kada je neka pravna norma na snazi ${ }^{49}$ a kriterij glasi:

LEX POSTERIOR DEROGAT LEGI PRIORI, odnosno kasniji zakon ili pravna norma derogira (mijenja, ukida) onu raniju.

Kriterij hijerarhije temelji se na formalnom autoritetu u smislu hijerarhije donositelja akta, a sam kriterij glasi:

LEX SUPERIOR DEROGAT LEGI INFERIORI, odnosno viši zakon ili pravna norma derogira (mijenja, ukida) onaj niži.

Treći kriterij, kriterij specijalnosti (za razliku od dvaju prethodnih) bavi se i počiva na predmetu pravne norme o kojoj se radi, a sam kriterij glasi:

LEX SPECIALIS DEROGAT LEGI GENERALI, odnosno specijalni zakon ili pravna norma derogira (mijenja, ukida) onaj opći.

Prima facie izgleda kao da u primjeni bio kojega od ovih kriterija nema problema ili barem nema većih problema. To, nažalost, jest tako samo kod klasičnog laičkog uvida, odnosno kod nepravničkog uvida. Pravo stanje stvari pokazuje da su tu problemi ne samo mogući, nego i razmjerno česti i veliki. Ipak, razlike postoje. Tako je kod prvog kriterija (LEX POSTERIOR DEROGAT LEGI PRIORI) najčešći i najveći problem razlikovanje između donošenja prave norme, njezina stupanja na snagu i početka primjene s jedne strane, te to što pravna norma koja je na snazi čini cjelinu, ali se najčešć ${ }^{50}$ sastoji od dijelova koji nisu istodobno donošeni, stupili na snagu i/ili se počeli primjenjivati. Kod drugog kriterija ${ }^{51}$ (LEX SUPERIOR DEROGAT LEGI INFERIORI) problemi su najrjeđi, ${ }^{52}$ ali je činjenica da je veliki problem npr. već i to što nije dvojbeno da su međunarodni ugovori po snazi iznad zakona, a ispod ustava, ali u praksi to ipak nije baš tako ako mislimo na odnos međunarodnog ugovora i Ustava, a da i ne spominjemo izostanak ustavnosudske kontrole međunarodnih ugovora. Treći kriterij, kao onaj koji se jedini bavi predmetom regulative (LEX SPECIALIS DEROGAT LEGI GENERALI) možda je i najopterećeniji problemima. Naime, koliko god je točno da će u najvećem broju slučajeva biti lako i već prima facie odrediti koja je pravna norma opća ili generalna, a koja posebna ili specijalna, to nije uvijek tako. Naime, koliko god je jasno da (načelno) Zakon o obveznim odnosima ima položaj općeg zakona prema Zakonu o

49 Nažalost, hrvatska legislativa bilježi slučajeve u kojima, izvan Ustavom utvrđenih gabarita i, kazali bismo, mogućnosti, razlikuje pojmove stupanja na snagu i početka primjene, pa djeluje kao da imamo pravnu normu koja je na snazi, ali se ne primjenjuje, što je contradictio in adiecto. Vidjeti tako Zakon o nasljeđivanju objavljen u NN 48/03. i njegove prijelazne i završne odredbe.

50 To je posebno naglašeno kod zakonodavne produkcije koja npr. postoji u hrvatskom pravu.

51 Vrijedi ponoviti da prvi i drugi kriterij uopće ne vode računa o predmetu regulative.

52 Ali zato postoje iznimke, pa je u Italiji zabilježeno da zakon derogira ustav, što je već kao mogućnost za mnoge contradictio in adiecto. Vidjeti tako u: Norberto Bobbio, op. cit., str. 134., bilješka broj 8 . 
sportu kao specijalnom, nije baš moguće isključiti slučajeve kada će baš na primjeru tih dvaju zakona zaključak možda biti obrnut ili barem bitno različit. ${ }^{53}$

Naravno, poseban problem nastaje u slučaju kada za isti problem razni kriteriji daju različit odgovor, što otvara potrebu za istraživanjem triju različitih situacija. Prva je sukob vremenskog i hijerarhijskog kriterija (hijerarhijski ima prednost), druga je sukob kriterija specijalnosti i vremenskog kriterija (ranija norma je specijalna, kasnija je opća, neki ocjenjuju kako postoji latentan sukob između tih dvaju pravila za rješavanje antinomija i rješenja su različita, čak toliko da postoji i pravilo lex posterior generalis non derogat priori speciali), ${ }^{54}$ treća je sukob između hijerarhijskog kriterija i kriterija specijalnosti (hijerarhijski ima prednost, ali ne uvijek, odnosno ne bez iznimki). ${ }^{55}$ Generalno treba zaključiti: kad nastane potreba rješavanja antinomije među kriterijima za rješavanje antinomija u takvom krajnjem slučaju, kada nedostaje kriterij za rješavanje sukoba kriterija - kriterij nad kriterijima jest kriterij pravednosti. Ovime se odgovor pravnika susreće s onim od čovjeka s ulice prema kojemu između dviju inkompatibilnih normi mora prevladati ona koja je najpravednija. ${ }^{56}$ Prema jednom drugom autoru, tada u obzir dolaze metajuridička rješenja, tj. rješenja u smislu pravednosti, pravičnosti, prirodnog prava, prirode stvari itd. ${ }^{57}$ razumno pri tome djeluje stav jednog autoriteta na tom području prema kojemu se sudac u takvim slučajevima mora ponašati tako da je pravo bez antinomija i da omogućava u svakom slučaju nalaženje nekog rješenja u skladu s pravom. ${ }^{58}$

\section{III.2.2. O PRAVNIM PRAZNINAMA}

Pravnu je prazninu najbolje i najlakše definirati kao područje koje zakonodavac nije uredio, nije regulirao, makar je to, naravno, mogao. Ona predstavlja poseban oblik konkretnog slučaja koji treba interpretirati i to takav za koji zakonodavac nije predvidio pravnu normu koja bi regulirala takve slučajeve. ${ }^{59}$ Pravna praznina neka je vrsta antinomije, makar postoji i stav (dosta logičan) kako je takva tvrdnja contradictio in adiecto, jer ako nešto nije popunjeno (bilo kako), onda ne može biti ni proturječnosti, odnosno antinomije.

Osnovni način popunjavanja tumačenja u širem smislu pomoću kojega se popunjavaju pravne praznine jest tzv. analogija, odnosno tumačenje po sličnosti. Analogija znači da se na slučaj koji nije reguliran, koji dakle predstavlja pravnu

53 Uz rizik usporedbi poput one o tome što je starije, kokoš ili jaje, treba barem spomenuti situaciju u kojoj Zakon o obveznim odnosima (jer Zakon o sportu o tome nema ni jedne jedine riječi) ima ulogu i specijalnog zakona kada se unutar pravnih standarda o ništetnosti uključuju pojedinosti iz Zakona o obveznim odnosima, a ne iz Zakona o sportu.

54 Norberto Bobbio, op. cit., str. 133.

55 Norberto Bobbio, op. cit., str. 134.

56 Norberto Bobbio, op. cit., str. 135.

57 Berislav Perić prema: Žaklina Harašić, op. cit., str. 59, bilješka broj 66 .

58 Chaim Perelman prema: Žaklina Harašić, op. cit., str. 59.

59 Vidjeti tako u: Oleg Mandić, op. cit., str. 142. 
prazninu, primijeni pravna norma predviđena za drugi slučaj koji je s njim sličan $i$ to baš zbog te sličnosti. Iako su moguće razne podjele prema raznim kriterijima, uobičajena je ona na zakonsku analogiju (analogia legis) i pravnu analogiju (analogia iuris), pri čemu se za zakonsku analogiju koristi i pojam analogia partialis ili djelomična analogija, a za pravnu analogia totalis ili potpuna analogija ${ }^{60}$ Pravne praznine mogu se podijeliti i na aksiologijske i institucionalne. ${ }^{61}$ Ove prve, aksiologijske, one su kod kojih zakonodavac nešto nije predvidio i, posljedično, zato nije regulirao, a institucionalne su one kod kojih je izostala samo precizna regulativa.

Smatra se da je, i kao interpretativni argument, argument prirode ili naravi stvari u funkciji popunjavanja pravnih praznina. ${ }^{62}$ Pravo je pitanje, pod uvjetom da je navedeni stav ispravan, do koje se granice tu smije ići. Drugim riječima, slično kao i kod ciljnog tumačenja kao takvog, kakav je odnos između opasnosti od ugroze pravne sigurnosti pretjeranim miješanjem u posao zakonodavca od strane tumača i opasnosti od loše pravne norme i posljedično lošeg pravnog sustava zbog (jedne ili više, veće ili manje) pravne praznine. Jedan od mogućih odgovora svakako leži i u ocjeni prirode ili naravi stvari.

\section{POSTAVLJANJE I ANALIZA PROBLEMA}

Sigurni smo kako će se opći dio ovoga teksta i te kako koristiti u analizi gotovo svakog članka Zakona o sportu. Zato se za sada zadovoljavamo samo s par primjera, smatrajući to početkom jedne vrlo sustavne i opsežne znanstvene analize koja bi u konačnici morala dovesti do kvalitetnih rezultata i promjene sadašnjeg stanja regulative na (bitno) bolje.

Kako smo već naprijed naveli, lex specialis derogat legi generali spada među tri načela za rješavanje antinomija i kao takvo predstavlja na neki način jedan od stupova ili temelja ukupnog pravnog sustava. To je načelo koje uspostavlja (makar ne samo i isključivo to načelo, tu je još mnogo toga, pa tako i preostala dva kriterija za rješavanje antinomija, učenje o pravnim prazninama, naravi ili prirodi stvari itd.) pravila prema kojima je jasno da je poseban ili specijalni propis, odnosno pravna norma jača (u smislu da ima prioritet ako postoji kolizija, uključujući tu i situaciju u kojoj strogo formalno antinomije ili kolizije i nema jer u barem jednoj pravnoj normi postoji pravna praznina) od one opće.

Polazeći od navedenoga, kao predmet istraživanja postavili smo odnos Zakona o obveznim odnosima i Zakona o sportu, a zatim i Zakona o vlasništvu i Zakona o sportu. ZOO je pri tome hrvatski mali građanski zakonik koji, s obzirom na to

60 Radomir D. Lukić, op. cit., str. 340.

61 Prema jednom autoru, to su početne i naknadne praznine - vidjeti tako u: Radomir D. Luikić, Tumačenje prava, Suvremena administracija, Beograd, 1961., str. 146.

62 Žaklina Harašić, op. cit., str. 90. Vidjeti više o mogućnosti popunjavanja pravnih praznina pomoću prirode ili naravi stvari vidjeti detaljno u: Mihajlo Vuković, Priroda stvari, Zbornik Pravnog fakulteta u Zagrebu, broj 3-4. (1957.), str. 291-303. 
da u Republici Hrvatskoj ne postoji građanski zakonik, ${ }^{63}$ ima i ulogu supstituta građanskog zakonika. Po naravi stvari, (rerum natura) iz navedenoga proizlazi i da je ZOO u položaju općeg prema posebnom jer općenitije pravne norme (za sada) ne samo da nema nego ni ne može biti. ZOS je, s druge strane, po opsegu mali zakon (cca 100 članaka), koji je već samim tim limitiran glede onoga što regulira. Slijedom toga, mnogo toga uopće nije regulirao (npr. ugovore), a mnogo toga je samo ,dotakao“ (npr. zabranu prenamjene javnih sportskih građevina). ${ }^{64}$ Slijedom navedenoga, potrebno je ispitati što je dopušteno i potrebno uraditi kako bismo popunili pravnu prazninu na planu regulative ugovora i prenamjene u Zakonu o sportu.

Glede ugovora, dvije polazne stvari potpuno su sigurne. Ugovori i ugovorno pravo (u ovom slučaju ugovorno sportsko pravo) iznimno su važni za sport i sportaše, posljedično i za društvo u cjelini. Budući da zakonodavac kod donošenja ZOO-a nije (barem ne posebno) vodio računa o sportu, postavlja se pitanje smije li tumač kod primjene u sportu i na sport, pozivajući se pri tome i na narav ili prirodu stvari kao argument odstupati od ZOO-a. ${ }^{65}$ Prema našem mišljenju, s obzirom na to da je alternativa prava katastrofa, odgovor je pozitivan i ograničenje su samo specifičnosti sportskog prava i ništa više. To znači, pored ostaloga, i zaštitu posebnih interesa maloljetnika sportaša. Na konkretnom primjeru to znači kako će se čl. 322. ZOO-a u dijelu o ,... ništetnosti, osim ako cilj povrijeđenog pravila ne upućuje na neku drugu pravnu posljedicu..." u slučaju primjene na maloljetnike u sportu tumačiti potpuno drukčije nego izvan sporta, svakako još više in favorem maloljetnika. Naime, maloljetnik je uvijek (pravno) hendikepiran već zato što je maloljetnik, ali u sportu je taj hendikep (ipak) barem dvostruki - ovisnost o roditelju ili skrbniku „pojačana“ je ovisnošću o treneru, sponzoru, klubu, savezu itd., što nije i ne može biti isto. Naravno, različitost je dijelom uvjetovana i time o kojem se sportu radi, o kojoj dobi, konkurenciji itd., ali osnovna postavka, potpuno sigurno, vrijedi uvijek.

Glede prenamjene, situacija je nešto složenija. Naime, osim jako izolirane odredbe iz Zakona o sportu, nema potrebnih odredbi u drugim zakonima koji bi ih mogli sadržavati, od ZV-a, preko zakona o gradnji i dalje. Zbog toga je nužno (jer bi u protivnom odredba iz Zakona o sportu bila potpuno besmislena u smislu neprovedivosti) popuniti pravnu prazninu, i to ne samo u Zakonu o sportu nego i u drugim propisima, na način da se smatra kako je nužno ovaj aspekt istražiti prigodom izdavanja bilo kakve isprave za gradnju (eventualno i lokacijske dozvole), moguće čak i na način da za propuštanje takvog činjenja bude primijenjena maksimalna

63 Bi li ga bilo dobro imati ili ne, praktično uopće nije pravo pitanje ili prava dvojba. Naime, da je to dvojbeno, onda ne bi Republika Hrvatska praktično bila usamljena članica EU bez toga zakonika, a ne bi se ni oni koji još nisu članovi (ali to i te kako žele biti) naprosto ,gurali“" kako bi što prije donijeli svoj građanski zakonik (Republika Srbija, Republika Makedonija, Republika Crna Gora).

64 Vidjeti u članku koji je prvi put u hrvatskom pravu izdvojio ovaj problem - Blanka Ivančić-Kačer, „Jedno specifično ograničenje prava vlasništva (prenamjena površine, uklanjanje ili prenamjena javne športske građevine)“", Zbornik radova Pravnog fakulteta u Splitu, god. 53., broj 1/2016 (119), str. 299-320.

${ }_{65}$ Posebna je dvojba ide li ta ovlast samo u pravcu neprimjene nečega ili i u pravcu kreiranja nečeg novog. 
moguća sankcija. To je pravi primjer popunjavanja pravna praznine, čak i bez nužne formalne promjene pravne norme. ${ }^{66}$

\section{ZAKLJUČAK}

Često se kaže kako je početak rješavanja nekog problema njegovo prepoznavanje. Naravno da je to točno, ali je ipak potrebna određena dorada. Naime, iako je prepoznavanje problema condicio sine qua non (budućeg) rješenja istog problema, to za one koji očekuju blagodat rješenja malo znači. I povijest i sadašnjost prepune su prepoznatih problema koji, barem za sada, nisu dočekali rješenja. Nama to jednostavno u 21. stoljeću ne može biti dovoljno dobro, naprotiv!

Dakle, činjenica koju nitko ozbiljan neće ni pokušati demantirati jest da u pravu općenito postoji problem rješavanja antinomija i to nije specifičnost samo hrvatskog prava, to je problem globalne naravi i države se međusobno razlikuju samo po tome koliko ga uspješno rješavaju. Problem s pravnim prazninama i načinom njihova popunjavanja možda je nešto manje jasan i prepoznat, ali ipak i nešto teži za rješavanje. Međutim, to što se priznaje postojanje problema, još uvijek je daleko od priznanja prioriteta, drugim riječima, u konkurenciji drugih prioriteta, prioritet rješavanja pravnih praznina i antinomija mora zasluženo dobiti visoki prioritet, što onda jamči žuran početak sustavnog i kvalitetnog rada struke na rješenju problema. Naravno, potrebno je znati da je to trajan proces, kod svakog novog propisa potrebno je poduzimati potrebne mjere i na planu izbjegavanja ili rješenja antinomija, ali i popunjavanja pravnih praznina.

Budući da praznina ima, i to dosta, onda je pravi put, barem kratkoročno, popunjavanje pravnih praznina bez donošenja novih pravnih normi ili formalnog popravljanja starih (postojećih), a nakon toga uvijek ima vremena za donošenje pravnih normi u sadržaju baš onom postignutom tumačenjem. Nije lako, ali je nužno priznati da imamo veliki problem i da nije dosta samo imati volju riješiti ga, nego ga valja i znati riješiti i donijeti odluku kako će se to učiniti. Na primjeru prenamjene javne sportske građevine to npr. znači i potrebu utvrđenja negativne pretpostavke da nešto nije javna sportska građevina već kod ishođenja bilo kakve dozvole za izgradnju, a naravno, i kod svih planskih dokumenata to treba učiniti razvidnim već prima facie (a ne skriveno u tekstualnom dijelu malim slovima).

${ }_{66} \mathrm{Na}$ početku teksta spomenuli smo i ZPP - po našem mišljenju, sporovi u sportu baš po naravi ili prirodi stvari, tim prije ali ne isključivo kada se radi o maloljetnicima, već de lege lata moraju imati zajamčeno žurno ili prekoredno rješavanje, slično kao radni i posjedovni sporovi. 


\section{RESOLVING ANTINOMIES AND IN PARTICULAR LEGAL GAPS IN THE EXAMPLE OF RELATIONS BETWEEN SPORTS ACT AND OBLIGATORY RELATIONS ACT}

In this paper, the authors have attempted to show and prove how antinomies and legal gaps in law are an area of great complaint, and a large and still unresolved Croatian positive law problem. Despite this, these problems are in no way acknowledged as big problems Rare professional and several academic texts bear witness to this. Of course, the authors do not claim that these are the greatest or most acute Croatian legal problems, but overall they deserve someone to start dealing with them systematically. After presenting a way of resolving antinomies and legal gaps in general, the authors have offered two concrete examples believing that they prove their theories. Both examples are related to sports law. One is related to the Ownership Act and the other to the Obligatory Obligations Act, that is, to two key laws of Croatian Civil Law.

Key words: antinomies, legal gaps, resolution, interpretation, law 